\title{
Exercise, fibrinogen, and other risk factors for ischaemic heart disease Caerphilly Prospective Heart Disease Study
}

\author{
Peter C Elwood, John WG Yarnell, Janet Pickering, Ann M Fehily, John R O'Brien
}

\begin{abstract}
Objective-To examine the associations between physical activity and a wide range of risk factors for ischaemic heart disease including fibrinogen concentration and viscosity.
\end{abstract}

Design-Cross sectional evidence from the 2398 men aged $50-64$ years in the Caerphilly Prospective Heart Disease Study.

Methods-Validated questionnaires were used to quantify energy expenditure on leisure activities and to grade activities related to occupation. Risk factors for heart disease examined included blood pressure, lipids, fibrinogen, and plasma viscosity. Possible confounding variables included smoking, employment, and prevalent heart disease (angina, previous myocardial infarction, and electrocardiographic evidence of ischaemia).

Results-Fibrinogen concentration was lower by $0.24 \mathrm{~g} / \mathrm{l}$ and viscosity by $0.026 \mathrm{cP}$ in the third of men who were most active in leisure activities (about $0.25 \times 1$ SD). $A$ weak positive relation was found with high density lipoprotein cholesterol, but none with total chlolesterol or fasting glucose concentrations or blood pressure. Triglyceride concentrations seem to be substantially lower in the most active men, although the evidence for this is not consistent. Work related activity showed relation with the lipid concentration but not with the haemostatic tests.

Conclusions-Leisure activities of all levels seem to affect haemostatic and lipid factors beneficially. These effects correspond to a difference in the risk of heart disease for an active man and a sedentary man of at least $7 \%$ or $8 \%$. Fasting triglyceride concentrations have already been shown to be strongly predictive of heart disease in this cohort of men, and the effect of exercise on this factor is also likely to confer benefit.

(Br Heart f 1993;69:183-187)

Studies in the United Kingdom by Morris, et $a,^{1-3}$ Shaper and Wannamethee, ${ }^{4}$ and others $^{56}$ have established that exercise protects against ischaemic heart disease. Recent meta-analyses have suggested a relative risk for a sedentary life style, compared with an active life style, of about 1.9 for coronary heart disease. ${ }^{56}$ The nature of the activity is, however, debated, and whereas there seems to be little doubt about the protective effect of leisure activity, the evidence for occupational activity is much less certain. Furthermore, the amount of activity required for benefit, and whether or not only strenuous activities are beneficial, is also debated.

The greatest uncertainties concern the mechanism through which activity affects risk of ischaemic heart disease. Small effects of regular activity on high density lipoprotein cholesterol concentration and on blood pressure have been repeatedly described, but the size of these is hardly sufficient to explain more than a small proportion of the benefit. Recently, a substantial effect of strenuous exercise on fibrinogen concentrations has been reported, but this study gave no indication of benefit from mild exercise. ${ }^{7}$

In this paper we report relation between leisure and occupational activity, and certain risk factors for ischaemic heart disease, in particular, plasma triglyceride and fibrinogen concentration and plasma viscosity.

\section{Patients and methods}

The Caerphilly Study is based on a cohort of men who have now been followed up for 10 years. All the data in this report come from the first re-examination of the men when they were aged 50-64 years. A total of 2398 men were seen $(85 \%$ of the men in the cohort). Data on leisure activity are available for 2386 of these together with data on activity at work for the 1250 who were in employment at the time of the examination.

The Minnesota leisure time activity questionnaire ${ }^{8}$ was given to each man by a trained observer. This enquires into a wide range of sporting and other activities and, from data on time and frequency, estimates of average energy expenditure are made in $\mathrm{kcal} / \mathrm{day}$. These can be summed to give the total energy expenditure on leisure activities, or the energy expenditure can be calculated solely for activities in which around $360 \mathrm{kcal}$ or more are expended an hour (for example, squash, soccer, jogging). This is referred to here as high intensity leisure energy expenditure and the men are divided both by this, and by their total leisure activities, into thirds, level 1 indicating the least active. Table 1 shows the
Llandough Hospital,

Penarth, South Glamorgan

Accepted for publication

27 August 1992 
Table 1 Daily energy expenditure in men

\begin{tabular}{|c|c|c|c|c|}
\hline & \multicolumn{2}{|l|}{ Employed } & \multicolumn{2}{|l|}{ Not employed } \\
\hline & No IHD (n) & $I H D(n)$ & No IHD (n) & $I H D(n)$ \\
\hline $\begin{array}{l}\text { Total leisure activity: } \\
\text { Lowest third ( } 152 \mathrm{kcal} / \text { day or less) } \\
\text { Middle third }(153-390 \mathrm{kcal} / \text { day) } \\
\text { Highest third (over } 390 \mathrm{kcal} / \text { day) }\end{array}$ & $\begin{array}{l}322 \\
356 \\
273\end{array}$ & $\begin{array}{r}112 \\
116 \\
77\end{array}$ & $\begin{array}{l}190 \\
205 \\
307\end{array}$ & $\begin{array}{l}169 \\
120 \\
136\end{array}$ \\
\hline $\begin{array}{l}\text { High intensity leisure activity: } \\
\text { Lowest third (nil) } \\
\text { Middle third (1-21 kcal/day) } \\
\text { Highest third (over } 21 \mathrm{kcal} / \mathrm{day})\end{array}$ & $\begin{array}{l}244 \\
324 \\
383\end{array}$ & $\begin{array}{r}85 \\
120 \\
100\end{array}$ & $\begin{array}{l}248 \\
233 \\
221\end{array}$ & $\begin{array}{r}213 \\
119 \\
93\end{array}$ \\
\hline $\begin{array}{l}\text { Work activity: } \\
\text { Lowest third } \\
\text { Middle third } \\
\text { Highest third }\end{array}$ & $\begin{array}{l}325 \\
334 \\
286\end{array}$ & $\begin{array}{r}120 \\
102 \\
83\end{array}$ & & \\
\hline
\end{tabular}

IHD, ischaemic heart disease.

\section{Results}

The validity of the Minnesota leisure time activity questionnaire in our population was assessed from the association of its estimates of energy expenditure with total energy intake estimated by a detailed dietary questionnaire given to every man, ${ }^{1314}$ and with pulse rate, a surrogate for physical fitness which, in turn, is associated with habitual exercise level. Energy expenditure in leisure activities showed highly significant relation with both total energy intake and pulse rate, and the presence of prevalent ischaemic heart disease had no significant interaction with these relations. Energy expenditure in high intensity leisure activities tends to be occasional, or spasmodic, but nevertheless there was a small excess in energy intake and a reduction in pulse rate in the most active men. Similarly, the scores of the health insurance plan questionnaire on work activity showed noticeable relation with total energy intake and with pulse rate. Total leisure energy expenditure was closely correlated with expenditure on high intensity activities $(r=0.36, \mathrm{p}<0.001)$ but not with activity at work $(r=-0.02)$.

Table 2 shows relation with possible confounding factors. For total leisure activity, correlations seem to be weak, other than for prevalent ischaemic heart disease for which there is a strong negative trend with increasing activity; this must represent the avoidance of exercise by men with symptoms of heart disease. Relations with high intensity activity are rather stronger and more consistent for some of the confounding factors: the more active men are slightly younger, fewer smoke, fewer are not in employment, and many fewer have evidence of prevalent ischaemic heart disease.

Table 3 shows the relations between energy expenditure and several risk factors for previous myocardial infarction, and myocardial ischaemia. ${ }^{10}$ All the methods have been described elsewhere. ${ }^{1112}$

Table 2 Associations between leisure energy expenditure and variables that may confound relation with risk factors for ischaemic heart disease

\begin{tabular}{|c|c|c|c|c|c|c|c|}
\hline & $\begin{array}{l}\text { No of } \\
\text { men }\end{array}$ & $\begin{array}{l}\text { Mean age } \\
(y r)\end{array}$ & $\begin{array}{l}\text { Mean } \\
\text { BMI }\end{array}$ & $\begin{array}{l}\text { Smokers } \\
(\%)\end{array}$ & $\begin{array}{l}\text { Ex-smokers } \\
(\%)\end{array}$ & $\begin{array}{l}\text { Not } \\
\text { employed (\%) }\end{array}$ & $\begin{array}{l}\text { Prevalent } \\
\text { IHD (\%) }\end{array}$ \\
\hline $\begin{array}{l}\text { Total leisure activity: } \\
\text { Lowest third } \\
\text { Middle third } \\
\text { Highest third }\end{array}$ & $\begin{array}{l}795 \\
797 \\
794\end{array}$ & $\begin{array}{l}57 \\
57 \\
57\end{array}$ & $\begin{array}{l}26 \cdot 6 \\
26 \cdot 5 \\
26 \cdot 2\end{array}$ & $\begin{array}{l}43 \\
42 \\
47\end{array}$ & $\begin{array}{l}38 \\
38 \\
38\end{array}$ & $\begin{array}{l}45 \\
41 \\
56\end{array}$ & $\begin{array}{l}35 \\
30 \\
27\end{array}$ \\
\hline $\begin{array}{l}\text { High intensity leisure activity: } \\
\text { Lowest third } \\
\text { Middle third } \\
\text { Highest third }\end{array}$ & $\begin{array}{l}792 \\
797 \\
797\end{array}$ & $\begin{array}{l}58 \\
57 \\
56\end{array}$ & $\begin{array}{l}26 \cdot 6 \\
26 \cdot 2 \\
26 \cdot 5\end{array}$ & $\begin{array}{l}48 \\
46 \\
38\end{array}$ & $\begin{array}{l}37 \\
36 \\
\mathbf{4 1}\end{array}$ & $\begin{array}{l}58 \\
44 \\
39\end{array}$ & $\begin{array}{l}38 \\
30 \\
24\end{array}$ \\
\hline
\end{tabular}

BMI, body mass index; IHD, ischaemic heart disease.

Table 3 Associations between leisure energy expenditure and risk factors of ischaemic heart disease

\begin{tabular}{|c|c|c|c|c|c|c|c|c|}
\hline & $\begin{array}{l}\text { Blood pressure } \\
\text { systolic:diastolic } \\
(\mathrm{mmHg})\end{array}$ & $\begin{array}{l}\text { Blood } \\
\text { glucose } \\
\text { (mmol/l) }\end{array}$ & $\begin{array}{l}\text { Total } \\
\text { cholesterol } \\
\text { (mmolll) }\end{array}$ & $\begin{array}{l}\text { HDL } \\
\text { cholesterol } \\
\text { (mmolll) }\end{array}$ & $\begin{array}{l}\text { Total } \\
\text { triglycerides } \\
\text { (mmolll) }\end{array}$ & $\begin{array}{l}\text { LDL } \\
\text { cholesterol } \\
\text { (mmolll) }\end{array}$ & $\begin{array}{l}\text { Fibrinogen } \\
(\mathrm{g} / \mathrm{l})\end{array}$ & $\begin{array}{l}\text { Plasma } \\
\text { viscosity } \\
\text { (cP) }\end{array}$ \\
\hline $\begin{array}{l}\text { Total leisure activity: } \\
\text { Lowest third } \\
\text { Middle third } \\
\text { Highest third } \\
\text { p Value }\end{array}$ & $\begin{array}{l}147: 85 \\
146: 85 \\
146: 84 \\
\text { NS }\end{array}$ & $\begin{array}{l}5 \cdot 45 \\
5 \cdot 37 \\
5 \cdot 35 \\
\text { NS }\end{array}$ & $\begin{array}{l}5 \cdot 66 \\
5 \cdot 56 \\
5 \cdot 68 \\
\text { NS }\end{array}$ & $\begin{array}{l}1.02 \\
1.02 \\
1.03 \\
\text { NS }\end{array}$ & $\begin{array}{l}1.73 \\
1.68 \\
1.67 \\
\text { NS }\end{array}$ & $\begin{array}{l}3 \cdot 71 \\
3.63 \\
3.76 \\
\text { NS }\end{array}$ & $\begin{array}{l}4.05 \\
3.95 \\
3.91 \\
<0.005\end{array}$ & $\begin{array}{l}1 \cdot 684 \\
1.674 \\
1 \cdot 670 \\
<0.005\end{array}$ \\
\hline $\begin{array}{l}\text { High intensity leisure activity: } \\
\text { Lowest third } \\
\text { Middle third } \\
\text { Highest third } \\
\text { p Value }\end{array}$ & $\begin{array}{l}148: 85 \\
147: 84 \\
145: 85 \\
<0.05\end{array}$ & $\begin{array}{l}5 \cdot 43 \\
5 \cdot 33 \\
5 \cdot 41 \\
\text { NS }\end{array}$ & $\begin{array}{l}5 \cdot 61 \\
5 \cdot 63 \\
5 \cdot 66 \\
\text { NS }\end{array}$ & $\begin{array}{l}1.00 \\
1.02 \\
1.04 \\
<0.005\end{array}$ & $\begin{array}{l}1.75 \\
1.68 \\
1.65 \\
<0.05\end{array}$ & $\begin{array}{l}3 \cdot 68 \\
3 \cdot 70 \\
3 \cdot 72 \\
\text { NS }\end{array}$ & $\begin{array}{l}4 \cdot 11 \\
3 \cdot 95 \\
3 \cdot 87 \\
<0 \cdot 0005\end{array}$ & $\begin{array}{l}1.691 \\
1.673 \\
1.665 \\
<0.0005\end{array}$ \\
\hline
\end{tabular}

The figures shown are means uncorrected for any confounding variable. Means for triglycerides are after log transformation; HDL, high density lipoprotein, LDL, low density lipoprotein. 
Table 4 Associations between leisure energy expenditure and haemostatic tests after standardisation for age, smoking, and prevalent ischaemic heart disease

\begin{tabular}{|c|c|c|c|c|}
\hline & \multicolumn{2}{|c|}{ Fibrinogen $(g / l)$} & \multicolumn{2}{|c|}{ Plasma viscosity (cP) } \\
\hline & Employed & Not employed & Employed & Not employed \\
\hline $\begin{array}{l}\text { Total leisure activity: } \\
\text { Lowest third } \\
\text { Middle third } \\
\text { Highest third } \\
\text { p Value }\end{array}$ & $\begin{array}{l}3 \cdot 92 \\
3 \cdot 89 \\
3 \cdot 85 \\
\text { NS }\end{array}$ & $\begin{aligned} & 4 \cdot 19 \\
& 4 \cdot 07 \\
& 3 \cdot 95 \\
< & 0.0005\end{aligned}$ & $\begin{array}{l}1.666 \\
1.665 \\
1.660 \\
\text { NS }\end{array}$ & $\begin{aligned} & 1.703 \\
& 1.690 \\
& 1.677 \\
&< 0.0005\end{aligned}$ \\
\hline $\begin{array}{l}\text { High intensity leisure activity: } \\
\text { Lowest third } \\
\text { Middle third } \\
\text { Highest third } \\
\text { p Value }\end{array}$ & $\begin{array}{l}3 \cdot 93 \\
3.86 \\
3 \cdot 89 \\
\text { NS }\end{array}$ & $\begin{aligned} & 4 \cdot 17 \\
& 4 \cdot 03 \\
& 3 \cdot 93 \\
&< 0.0005\end{aligned}$ & $\begin{array}{l}1.666 \\
1.662 \\
1.664 \\
\text { NS }\end{array}$ & $\begin{aligned} & 1.704 \\
& 1.685 \\
& 1.672 \\
&< 0.0005\end{aligned}$ \\
\hline
\end{tabular}

ischaemic heart disease. There is a weak positive relation with high density lipoprotein cholesterol and a somewhat stronger negative trend with triglyceride concentrations. Strong correlations are also apparent with plasma fibrinogen and plasma viscosity.

The data for lipids were examined in detail. Standardisation for age, smoking, employment, and prevalent ischaemic heart disease had virtually no effect on correlations with cholesterol and high density lipoprotein cholesterol concentrations. For triglycerides, prevalent ischaemic heart disease interacts significantly with exercise. Examination of the raw data showed that among the third of men with the highest levels of exercise, both total and high intensity, there were a number with unusually high triglyceride concentrations. Although there is no reason to exclude these, it is an unfortunate chance occurrence. In the absence of any interaction with prevalent ischaemic heart disease for the other lipids, we believe that it is reasonable to accept the data on triglycerides for the men with no prevalent ischaemic heart disease as most likely to represent the true effect of exercise, namely a difference of 0.14 to $0.19 \mathrm{mmol} / 1$ in mean triglyceride concentration (about $16 \%-22 \%$ of $1 \mathrm{SD}$ ) in the most active third of men compared with the least active third.

Fibrinogen concentration and viscosity were then examined in detail (table 4). Significant interactions occurred with employment but this was because the employed men had a smaller range of activity levels than those not employed. For fibrinogen and plasma viscosity there are negative correlations with exercise, and in the men who were not employed these are equivalent to $27 \%-34 \%$ of $1 \mathrm{SD}$.

Finally, table 5 shows the associations between work related activity and the various risk factors for ischaemic heart disease. Only the relations with high density lipoprotein cholesterol and triglycerides concentrations are significant and these are about the same as with leisure activities. There is no evidence of any association with the haemostatic factors.

\section{Discussion}

A protective effect of exercise on the incidence and the mortality of ischaemic heart disease has now been shown in many studies. ${ }^{1-4} 15-21$ In an overview, Berlin and Colditz remarked that the better the studies were methodologically, the larger the estimate of benefit. $^{6}$

Interest now focuses on whether or not levels of activity that are less than vigorous are protective, whether or not activity at work is protective, and what are the mechanisms through which exercise confers benefit.

We find no association between exercise level and body mass index and the effect on blood pressure seems likely, at most, to be small. Several studies have reported a weak negative relation, but both the multiple risk factor intervention trial ${ }^{20}$ study and the regional heart study $^{4}$ suggest a shallow J shaped relation with slightly increased pressures at the highest energy expenditure. Furthermore, the results of trials of exercise training on blood pressure are equivocal. Some have detected a small fall ${ }^{22}$ whereas others have not, but most of the trials have been small and short-term. By contrast, a large and carefully controlled trial of patients with mild essential hypertension detected no benefit from four months of aerobic training. ${ }^{23}$

Our results for total cholesterol agree with other publications. No major study seems to have found evidence of any important relation, although Connelly et al $^{7}$ found cholesterol concentrations to be significantly lower (by about $2 \%$ ) in men who exercised strenuously. High density lipoprotein cholesterol concentration, on the other hand, has been shown in many studies to be positively related to level of activity. In some studies the effect described has been appreciable, around $30 \%$ of $1 \mathrm{SD}^{24}$ but in the recent report from the regional heart study higher concentrations were confined to the men who were vigorously active, and amounted to only about $3 \%$ of the overall mean. ${ }^{4}$ Intervention trials have generally shown that an increase in activity leads to a rise in concentrations of high density lipoprotein cholesterol ${ }^{25}$ but most of these

Table 5 Associations between leisure energy expenditure at work and risk factors for ischaemic heart disease (IHD). All the figures have been standardised for age, smoking, and prevalent IHD.

\begin{tabular}{|c|c|c|c|c|c|c|c|c|}
\hline & $\begin{array}{l}\text { Blood pressure } \\
\text { systolic:diastolic } \\
\text { (mmHg) }\end{array}$ & $\begin{array}{l}\text { Blood } \\
\text { glucose } \\
\text { (mmolll) }\end{array}$ & $\begin{array}{l}\text { Total } \\
\text { cholesterol } \\
\text { (mmol/l) }\end{array}$ & $\begin{array}{l}\text { HDL } \\
\text { cholesterol } \\
\text { (mmol/l) }\end{array}$ & $\begin{array}{l}\text { Total } \\
\text { triglycerides } \\
\text { (mmolll) }\end{array}$ & $\begin{array}{l}\text { LDL } \\
\text { cholesterol } \\
(\mathrm{mmol} / \mathrm{l})\end{array}$ & $\begin{array}{l}\text { Fibrinogen } \\
(\mathrm{g} / \mathrm{l})\end{array}$ & $\begin{array}{l}\text { Plasma } \\
\text { viscosity } \\
\text { (cP) }\end{array}$ \\
\hline $\begin{array}{l}\text { Work activity: } \\
\text { Lowest third } \\
\text { Middle third } \\
\text { Highest third } \\
\text { Test for trend }\end{array}$ & $\begin{array}{l}144: 85 \\
145: 85 \\
147: 85 \\
\text { NS }\end{array}$ & $\begin{array}{l}5 \cdot 37 \\
5 \cdot 30 \\
5 \cdot 35 \\
\text { NS }\end{array}$ & $\begin{array}{l}5 \cdot 59 \\
5 \cdot 60 \\
5 \cdot 61 \\
\text { NS }\end{array}$ & $\begin{array}{l}1.02 \\
1.03 \\
1.08 \\
<0.005\end{array}$ & $\begin{array}{l}1.72 \\
1.60 \\
1.59 \\
<0.05\end{array}$ & $\begin{array}{l}3 \cdot 66 \\
3 \cdot 69 \\
3 \cdot 68 \\
\text { NS }\end{array}$ & $\begin{array}{l}3 \cdot 83 \\
3 \cdot 86 \\
3 \cdot 84 \\
\text { NS }\end{array}$ & $\begin{array}{l}1.664 \\
1.658 \\
1.662 \\
\text { NS }\end{array}$ \\
\hline
\end{tabular}

The figures shown are means uncorrected for any confounding variable. Means for triglycerides are after log transformation; HDL, high density lipoprotein, LDL, low density lipoprotein. 
have tested short- term high intensity training programmes in younger subjects. ${ }^{26}$

The data we present here on triglycerides are of particular value, both because these were estimated on fasting blood samples, ${ }^{11}$ and because a very strong predictive power for ischaemic heart disease has already been shown for triglyceride concentrations in this same cohort of men. ${ }^{27}$ The effect is appreciable, a difference of $16 \%$ to $22 \%$ of 1 SD between thirds of men defined by activity level. The interaction with prevalent ischaemic heart disease is unexpected and it is difficult to imagine that through the same mechanism, exercise might be beneficial in healthy men but harmful in men with evidence of ischaemic heart disease. Unfortunately, evidence on triglycerides is sparse. It has been noted that the more physically active subjects generally have lower concentrations of triglyceride ${ }^{28}$ and in an extensive review of intervention studies Cauley, et al found that in most of those in which triglycerides have been monitored, exercise had led to a fall, ${ }^{26}$ but again almost all of these results come from small and short-term studies.

Data on haemostatic factors is of interest because the effect of exercise on both fibrinogen concentration and viscosity seems large (around $0.25 \times 1 \mathrm{SD}$ ) and because both of these factors have been shown to be strongly predictive of ischaemic heart disease in this same population sample of men. ${ }^{29}$ The interaction with employment was unexpected, but on the other hand the range of exercise levels is broader in the unemployed than in the employed men. We have already described the effect of employment and have shown that it is independent of all the likely confounding factors. ${ }^{30}$

The data of Connelly et $a l^{7}$ show a rather large difference (just over 1 SD) between men who took mild and those who took strenuous exercise, but there was no difference between their mild group and those who said they took no exercise at all. A study of 639 men in Gothenburg ${ }^{31}$ showed that the most active men had lower fibrinogen concentrations by about $40 \%$ of 1 SD than the least active. Other studies of joggers, ${ }^{32}$ athletes, ${ }^{33}$ and experimental studies of training $^{34}{ }^{35}$ all give evidence of lower fibrinogen concentration, or lower viscosity with exercise. Indeed, evidence from some of these studies led Ernst to comment that "exercise can be looked upon as one (side effect free) form of haemorheological therapy." 34

Questions remain as to which type of activity is beneficial. Our data suggest marginally greater benefits on some of the ischaemic heart disease risk factors from high intensity activity, than from total leisure activity. The differences are small and exclusion of all high intensity activities has only trivial effects on the relation with total leisure energy expenditure. The hypothesis that only vigorous exercise promotes cardiovascular health was first proposed by Morris and his colleagues. ${ }^{1}$ It has been subsequently defended, ${ }^{23}$ and is sistent with the data of Connelly et $a l^{7}$ which show effects on fibrinogen only with strenuous exercise. Shaper and Wannamethee, however, have challenged this and in their data $^{4}$ and in those from the Puerto Rico study ${ }^{18}$ there is a gradient of protection up to levels of moderately vigorous activity but the most active men had an increased rate of heart attacks.

The relevance of work activity to ischaemic heart disease is not clear. In their overview Berlin and Colditz find a reduction in the mortality of men in active occupations that is similar to that associated with leisure activity. ${ }^{6}$ Others, however, find no correlation. ${ }^{17}$ It is of interest, therefore, that within our cohort there is evidence of associations of work activity with two lipid fractions but not with either haemostatic factor.

Finally, it is of interest to estimate the reductions in the incidence of ischaemic heart disease that are likely to be explained by the effects of exercise on the haemostatic tests that we have described. This we can do because we have data for incidence of ischaemic heart disease in the same cohort of men, although these relate to the five years before the measurements of activity. ${ }^{29}$ The limits of the $95 \%$ range of the distribution of activity levels can be taken to represent a sedentary man (the $5^{\text {th }}$ centile) and an active man (the $95^{\text {th }}$ centile). The mean differences in the concentrations are $0.15 \mathrm{mmol} / 1$ triglycerides, $0.25 \mathrm{~g} / 1$ fibrinogen, and $0.028 \mathrm{cP}$ plasma viscosity. Application of these figures to the data for incidence of ischaemic heart disease within the same cohort ${ }^{27} 29$ indicates that the risk of an ischaemic heart disease event would on average be reduced by exercise by around $3 \%$ or $4 \%$ with respect to triglycerides and $7 \%$ to $8 \%$ with respect to either fibrinogen or viscosity, independent of all other risk factors. Although fibrinogen concentration and viscosity are strongly interrelated, triglyceride concentration is independent of both and so the two separate effects could be additive. Furthermore, these might be underestimates of the true effects because regression dilution, consequent upon errors in the measurement of the independent variable (exercise levels), may be considerable.

1 Morris JN, Chave SPW, Adam C, Sirey C, Epstein L, Sheehan DJ. Vigorous exercise in leisure-time and the incidence of coronary heart disease. Lancet 1973;i: 333-9.

2 Morris JN, Everitt MG, Pollard R, Chave SPW. Vigorous exercise in leisure-time: protection against coronary heart disease. Lancet 1980; II:1207-10.

3 Morris NN, Clayton DG, Everitt MG, Semmence AM, Burgess EH. Exercise in leisure time: coronary attack Burgess EH. Exercise in leisure time: coro

4 Shaper AG, Wannamethee G. Physical activity and ischaemic heart disease in middle-aged British men. $\mathrm{Br}$ Heart $\mathcal{F} 1991 ; 66: 384-94$.

5 Powell KE, Thompson PD, Caspersen CJ, Kendrick JS. Physical activity and the incidence of coronary heart disease. Annual Review of Public Health 1987;8:253-87.

6 Berlin JA, Colditz GA. A meta-analysis of physical activity in the prevention of coronary heart disease. $A m \mathcal{F}$ Epidemiol 1990;132:612-28.

7 Connelly JB, Cooper JA, Meade TW. Strenuous exercise, plasma fibrinogen and factor VII activity. Br Heart $\mathcal{f}$ 1992;67:351-4

8 Taylor HL, Jacobs DR, Schucker B, Knudsen J, Leon AS, DeBacker G. A questionnaire for the assessment of 741-55. 
9 Shapiro S, Weinblatt E, Frank CW, Sager RV. The HIP study of incidence and prognosis of coronary heart disease. Preliminary findings on incidence of myoca

10 Rose GA, Blackburn H. Cardiovascular survey methods. 1st ed. Geneva: World Health Organisation 1968.

11 Caerphilly and Speedwell Collaborative Group. Caerphilly and Speedwell collaborative heart disease studies. f Epidemiol Community Health 1984;38:259-62.

12 Medical Research Council Epidemiology Unit. The Caerphilly collaborative heart disease studies: project description and manual of operations. Cardiff: MRC Epidemiology Unit, 1985 .

13 Yarnell JWG, Fehily AM, Milbank JE, Sweetnam PM, Walker CL. A short dietary questionnaire for use in an epidemiological study: comparison with weighed dietary records. Human Nutrition:Applied Nutrition 1983; records. $37 \mathbf{a}: 103-12$.

14 Fehily AM, Yarnell JWG, Butland BK. Diet and ischaemic heart disease in the Caerphilly Study. Human Nutrition:Applied Nutrition 1987;41a:319-26.

15 Blair SN, Kohl HW, Paffenbarger RS, Clark DG, Cooper $\mathrm{KH}$, Gibbons LW. Physical fitness and all-cause mortality. A prospective study of healthy men and women. fAMA 1989;262:2395-401.

16 Ekelund L, Haskell WL, Johnson JL, Whaley FS, Criqui MH, Sheps DS. Physical fitness as a predictor of cardiovascular mortality in asymptomatic North American men. N Engl f Med 1988;319:1379-84.

17 Folsom AR, Caspersen CJ, Taylor HL, Jacobs DR, Luepker RV, Gomez-Marin O, et al. Leisure time physical activity and its relationship to coronary risk factors in a population based sample. The Minnesota heart sura population based sample. The Minm

18 Garcia-Palmieri MR, Costas P, Cruz-Vidal M, Sorlie PD, Havlik RJ. Increased physical activity: a protective factor against heart attacks in Puerto Rico. $\mathrm{Am} \mathcal{F}$ Cardiol 1982;50:749-55.

19 Kannel WB, Sorlie P. Some health benefits of physical activity. Arch Intern Med 1979;139:857-61.

20 Leon AS, Connett J, Jacobs DR, Rauramaa R. Leisuretime physical activity levels and risk of coronary heart disease and death. The multiple risk factor intervention trial. $¥ A M A$ 1987;258:2388-95.

21 Salonen JT, Slater JS, Tuomilehto J, Rauramaa R. Leisure time and occupational physical activity: risk of death from ischaemic heart disease. Am $\mathfrak{f}$ Epidemiol from ischaemic
22 Hagberg JM, Seals DR. Exercise training and hypertension. Acta Med Scand 1986;711 (suppl): 131-6.

23 Blumenthal JA, Siegel WC, Appelbaum M. Failure of exercise to reduce blood pressure in patients with mild hypertension. Results of a ran

24 Williams P, Robinson D, Beuley A. High density lipopro1979;i:72-5.

25 Wood PD, Haskell W, Klein H, Lewis S, Stern MP. The distribution of plasma lipoproteins in middle-aged male runners. Metabolism 1976;25:1249-57.

26 Cauley JA, Kriska AM, LaPorte RE, Sandler RB, Pambianco G. A two year randomised exercise trial in older women: effects on HDL-cholesterol. Atherosclerosis 1987;66:247-58

27 Bainton $D$, Miller NE, Bolton $\mathrm{CH}$, Yarnell JWG Sweetnam PM, Baker IA, et al. Plasma triglyceride and high density lipoprotein cholesterol as predictors of ischaemic heart disease in British men. Br Heart f 1992; 68:60-6.

28 Haskell WL. The influence of exercise training on plasma lipids and lipoproteins in health and disease. Acta Med Scand 1986;711 (suppl):25-37.

29 Yarnell JWG, Baker IA, Sweetnam PM, Bainton D, O'Brien JR, Whitehead PJ, Elwood PC. Fibrinogen, viscosity and white blood cell count are major risk factors for ischaemic heart disease. The Caerphilly and Speedwell collaborative heart disease studies. Circulation 1991;83:836-44.

30 Gilbert JF, Gallacher JEJ, Sweetnam PM, Yarnell JWG, Elwood PC. Employment status and risk factors for Elwood PC. Employment status and risk factors for
ischaemic heart disease: the Caerphilly study. The ischaemic heart disease:
Statistician 1990;39:385-90.

31 Rosengren A, Wilhelmsen L, Welin L, Tsipogianni A, Teger-Nilsson A, Wedel $\mathrm{H}$. Social influences and cardiovascular risk factors as determinants of plasma fibrinogen concentration in a general population sample of middle aged men. BMF 1990;300:634- 8.

32 Charm SE, Paz H, Kurland GS. Reduced plasma viscosity among joggers compared with non-joggers. Biorheology 1979;16:185-9.

33 Ernst $\mathrm{E}$. Changes in blood rheology produced by exercise. fAMA 1985;253:2962-3.

34 Ernst E. Influence of regular physical activity on blood rheology. Eur Heart $\mathcal{f} 1987 ; 8$ (suppl G):59-62.

35 Ernst E, Matrai AM. Intermittent claudication, exercise and blood rheology. Circulation 1987;76:1110-4. 